\title{
Tranilast enhances the anti-tumor effects of tamoxifen on human breast cancer cells in vitro
}

\author{
Sara Darakhshan ${ }^{1}$ and Ali Ghanbari ${ }^{2^{*}}$ \\ A correction to this article has been published: http://www.jbiomedsci.com/content/20/1/89
}

\begin{abstract}
Background: Tamoxifen is the most widely used anti-estrogen for the treatment of breast cancer. Studies show that the combination therapy with other substances that helps the activity of tamoxifen. The objective of this study was to evaluate the effect of tamoxifen when used in combination with tranilast on human breast cancer cells.

Results: Two MCF-7 and MDA-MB-231 human breast cancer cell lines were treated with tamoxifen and/or tranilast. The cell viability and cytotoxicity was assessed using MTT and LDH assays; the apoptotic effects were examined by TUNEL assay, acridine orange/ethidium bromide staining and DNA laddering, also the expression levels of bax and bcl-2 genes were detected by real-time RT-PCR. The mRNA expression of TGF- $\beta$ ligands and receptors examined using real-time RT-PCR and TGF- $\beta 1$ protein secretion levels were also evaluated by ELISA assay. Inhibitory effect of these drugs on invasion and metastasis were tested by wound healing and matrigel invasion assay.

We found that combination of these drugs led to a marked increase in growth and proliferation inhibition compared to either agent alone. Furthermore, bax and bcl-2 affected by tamoxifen and/or tranilast and resulted in a significant increase in bax and decrease in bcl-2 mRNA expression. In addition, treatment with tamoxifen and/or tranilast resulted in significant decreased in TGF- $\beta 1,2,3$, TGF- $\beta R$ I and II mRNA and TGF- $\beta 1$ protein levels while TGF- $\beta$ RIII mRNA level was increased and invasion was also inhibited.
\end{abstract}

Conclusions: These findings indicate that tranilast, by synergistic effect, enhances the activity of tamoxifen and the TGF- $\beta$ pathway is a target for this combination therapy, therefore; we propose that this combined treatment may be suitable selection in prevention of breast cancer.

Keywords: Breast cancer, Tamoxifen, Tranilast, Apoptosis, Transforming growth factor-beta

\section{Background}

Apoptosis or programmed cell death provides an effective non-inflammatory way to remove redundant or damaged cells from tissues thereby acquiring tissue homeostasis [1]. Defective apoptosis and, in part, inappropriate proliferation, underpin the process of tumorigenesis [2] in addition, resistance to apoptosis is an important feature for cancer cells to invasion [3].

As estrogen significantly associated with the initiation, progression, even recurrence of breast cancer [4], anti-estrogens have important therapeutic potential in endocrine therapy for breast cancer. Tamoxifen ((Z)-1-\{4-

\footnotetext{
* Correspondence: aghanbari@kums.ac.ir

${ }^{2}$ Fertility and Infertility Research Center, Kermanshah University of Medical Sciences, Kermanshah, Iran

Full list of author information is available at the end of the article
}

[2-(dimethylamino) ethoxy] phenyl\}-1, 2-diphenyl-1-butene) (TAM) is a synthetic non-steroidal anti-estrogenic drug that widely used for the treatment or prevention of breast carcinoma [5]. Despite the relative safety and significant anti-neoplastic activities of tamoxifen, most initially responsive breast tumors develop resistance to its [6]. Even though an improved understanding, resistance to anti-estrogen therapy remains a significant clinical problem. However, combination therapies of tamoxifen with other drugs that aimed at the signaling pathways underlying the development of resistance may be a potential means of delaying the arrival of resistance.

One cytokine that may contribute to the metastatic potential and possibly tamoxifen resistance of tumor cells is transforming growth factor beta (TGF- $\beta$ ). There is three isoforms of TGF- $\beta$ : TGF- $\beta 1,-\beta 2$ and $-\beta 3$ [7]. Cell functions

\section{() Biomed Central}


regulation by TGF- $\beta$ s arises from his interaction with three discrete cell surface receptors, TGF- $\beta$ RI, II and III [8]. TGF- $\beta$ family regulates a diverse range of epithelial cell processes including proliferation, apoptosis, differentiation, adhesion and migration in a cell- and context-specific manner [9]. The multiplicity of TGF- $\beta$ actions in nearly all cell types suggests that these have a complex and pivotal role in several physiological and pathological processes. TGF- $\beta$ have an important role in normal mammary as a potent inhibitor of epithelial proliferation and regulator of mammary growth and development [10]. In addition, TGF- $\beta$ plays complex roles in breast carcinogenesis. Early in mammary carcinogenesis the TGF- $\beta$ signaling pathway functions as a tumor suppressor [11] however, at later stages, levels of TGF- $\beta$ increase with tumor progression suggesting that TGF- $\beta$ is now stimulating breast cancer progression [12].

The drug tranilast (N-[3', 4'-dimethoxycinnamoyl]anthranilic acid), an anti-allergic agent, has been applied for bronchial asthma, allergic rhinitis and atopic dermatitis, also suppresses collagen synthesis in keloid or hypertrophic scars $[13,14]$. The inhibitory effect of tranilast in different cell types is probably by antagonizing and inhibiting synthesis and secretion of TGF- $\beta$ [15-19]. Since tranilast responsibilities through TGF- $\beta$ pathway, it seems also tamoxifen influences this pathway [20], we hypothesize that combination of tamoxifen and tranilast may an appropriate therapeutic option for breast cancer management. In this paper, possible synergistic effect of tamoxifen with tranilast was examined in the hope of creating a more effective anti-tumor treatment strategy.

\section{Methods}

\section{Cell lines \& drugs}

MCF-7 (noninvasive human breast adenocarsinoma, ERand PR-positive) and MDA-MB-231 (metastatic human breast adenocarsinoma, ER-, PR- and HER2-negative) obtained from the National Cell bank of Iran (NCBI), were grown in RPMI-1640 media supplemented with 10\% (v/v) fetal calf serum (FCS) and penicillin/streptomycin antibiotics. Cultures were maintained at $37^{\circ} \mathrm{C}$ in a humidified atmosphere of $5 \% \mathrm{CO}_{2}$ in air. TAM and tranilast were purchased from Enzo Life Sciences and dissolved in dimethyl sulfoxide (DMSO) so that the final dimethyl sulfoxide concentration in experimental wells did not exceed $0.5 \%(\mathrm{v} / \mathrm{v})$. Aliquots of a $1000 \mu \mathrm{M}$ stock solution of TAM and tranilast were stored in dark at $-70^{\circ} \mathrm{C}$, defrosted and diluted with cell culture medium to the desired concentration before use.

The concentrations used alone treatment were the following: TAM: 1, 2, 5, 10 and $20 \mu \mathrm{M}$; tranilast: 10, 20, 50, 100 and $200 \mu \mathrm{M}$. The treatment combinations used were: $2 \mu \mathrm{M}$ of TAM with different concentrations of tranilast: $10,20,50,100$, and $200 \mu \mathrm{M}$ for $48 \mathrm{~h}$.

\section{Cell viability measurement}

Cytotoxic effect of TAM and tranilast was determined by MTT test. MCF-7 or MDA-MB-231 cells were seeded in 96-well culture plates at $10^{4}$ cells/well density. Cells were allowed to attach for $24 \mathrm{~h}$ before drugs were added to the medium. All drug concentrations were tested in triplicate wells and the assays were performed in three separate experiments. Following $48 \mathrm{~h}$ exposure at $37^{\circ} \mathrm{C}$ and 5\% $\mathrm{CO}_{2}, 20 \mu \mathrm{l}$ MTT solution (Cell Growth Assay; Merck) (5 $\mathrm{mg} / \mathrm{ml}$ in PBS) was added to each well and incubated for $4 \mathrm{~h}$ at $37^{\circ} \mathrm{C}$. The medium with MTT were removed, and $100 \mu \mathrm{l}$ DMSO was added to dissolve formazan crystals at room temperature for $30 \mathrm{~min}$. The optical density (OD) of each well was measured using an ELISA reader at $570 \mathrm{~nm}$. The percentage of cell viability was calculated according to the following equation:

$$
\begin{aligned}
\text { Cell viability }(\%)= & {\left[A_{570}(\text { sample }) / A_{570}(\text { control })\right] } \\
& \times 100 \%
\end{aligned}
$$

\section{Lactate dehydrogenase (LDH) assay}

MCF-7 or MDA-MB-231 cells were cultured in 96-well plates $\left(1 \times 10^{4}\right.$ cells/well $)$. The plates were incubated overnight at $37^{\circ} \mathrm{C}$ and on the next day, $300 \mu$ l of culture media containing drug doses were added to each well, and the plates were incubated at $37^{\circ} \mathrm{C}$ in $5 \% \mathrm{CO}_{2} .48 \mathrm{~h}$ later, $100 \mu \mathrm{l}$ of medium from each well was carefully transferred to new plates. $100 \mu \mathrm{l}$ of LDH substrate prepared according to the manufacturer's procedure (Cytotoxicity Detection Kit, Roche Chemical Co.) was added to each well. After $20 \mathrm{~min}$ shaking at room temperature lactate dehydrogenase activity was determined by change in absorbance at $490 \mathrm{~nm}$. All drug concentrations were tested at least in triplicate wells and the assays were repeated independently three times.

\section{TUNEL assay}

TUNEL was carried out using an In Situ Cell Death Detection Kit, AP (Roche Diagnostics; Germany) according to the manufacturer's instructions. Briefly, after $48 \mathrm{~h}$ treatment by $2 \mu \mathrm{M}$ TAM, $200 \mu \mathrm{M}$ tranilast or a combination two, the cells were fixed by adding $4 \%$ paraformaldehyde for $30 \mathrm{~min}$. The fixed cells were washed in PBS, permeabilized with $0.1 \%$ Triton X-100 for 5 min on ice, and then incubated with $50 \mu \mathrm{l}$ of terminal deoxynucleotidyl transferase end-labeling solution for $60 \mathrm{~min}$ at $37^{\circ} \mathrm{C}$ in a humidified chamber in the dark. Then, cells were counterstained in PI staining solution for $4 \mathrm{~min}$ at room temperature in the dark. The percentage of positively stained cells per total number of cells was counted under a fluorescence microscope at a magnification of $40 x$ in five random fields and averaged. 
Acridine orange/ethidium bromide (AO/EB) staining

MCF-7 or MDA-MB-231 were plated in 24-well plates $\left(10^{5}\right.$ cells/well $)$ and incubated overnight in a humidified $5 \% \mathrm{CO}_{2}$ incubator at $37^{\circ} \mathrm{C}$ for $24 \mathrm{~h}$. At that time, cells treated with $2 \mu \mathrm{M}$ TAM, $200 \mu \mathrm{M}$ tranilast or a combination two and incubated for $48 \mathrm{~h}$. After that, cells harvested and stained with $\mathrm{AO} / \mathrm{EB}$ dye mix (1 part of $100 \mu \mathrm{g} /$ $\mathrm{ml}$ of $\mathrm{AO}$ and 1 part of $100 \mu \mathrm{g} / \mathrm{ml}$ of EB in PBS) on a clean microscope slide. The live, apoptotic and necrotic cells were observed under the fluorescent microscope at a magnification of 40x. Experiments were repeated for twice.

\section{DNA gel electrophoresis (DNA laddering)}

The MCF-7 and MDA-MB-231 cells were grown in absence or presence of $2 \mu \mathrm{M}$ TAM, $200 \mu \mathrm{M}$ tranilast and combination of both for $48 \mathrm{~h}$. Cellular DNA was then extracted from each cell line. The cells were lysed with $1 \%$ SDS in TE buffer and digested with proteinase $\mathrm{K}$ for $4 \mathrm{~h}$ at $56^{\circ} \mathrm{C}$. The samples were extracted with phenol and chloroform and the DNA was precipitated with a 1/10 volume of $3 \mathrm{M}$ sodium acetate and an equal volume of ethanol, pelleted at 13,000 $\times \mathrm{g}$ and resuspended in TE buffer and $10 \mathrm{mg} / \mathrm{ml}$ of DNase-free RNase for $30 \mathrm{~min}$ at $37^{\circ} \mathrm{C}$. Finally, extracted genomic DNAs was loaded and fractioned on $2 \%$ agarose gels; gels were stained with ethidium bromide and photographed. When DNA extracted from apoptotic cells is subjected to gel electrophoresis, a typical internucleosomal "ladder" of DNA fragments is produced.

\section{Real-time quantitative PCR (RQ-PCR) analysis}

Total cellular RNAs were extracted from control or drug-treated cell pellets, $48 \mathrm{~h}$ after treatment with $2 \mu \mathrm{M}$ TAM, $200 \mu \mathrm{M}$ tranilast and combination both, using RNeasy Mini kit (Qiagen) in accordance with the manufacturer"s protocol. First strand cDNA was synthesized using QuantiTect Reverse Transcription Kit (Qiagen). Numbers of cDNA copies were calculated from the absorbance at $260 \mathrm{~nm}$. Aliquots of the cDNA were combined with the QuantiFast ${ }^{\circ}$ SYBER $^{\circ}$ Green PCR Master Mix from Qiagen and primers, and assayed in triplicate using a Rotor-Gene 6000 real-time RT-PCR. The primers were designed using the program BioEdit and BLAST searches (http://www.ncbi.nlm.nih.gov) carried out to confirm specificity of the selected nucleotide sequences and properties of primers are summarized in Table 1.

Analysis and fold differences were determined using the comparative $2{ }_{\mathrm{T}}^{-\Delta \Delta C}$ method. Quantitative values were obtained from the threshold cycle $\left(C_{T}\right)$ number at which the increase in fluorescent signal was associated with an exponential increase of PCR product. The $\mathrm{C}_{\mathrm{T}}$ values from samples were plotted on the standard curve and the copy numbers was calculated with GAPDH as the internal control.

\begin{tabular}{|c|c|c|c|}
\hline Target mRNA & & Sequence $\left(5^{\prime}\right.$ to $\left.3^{\prime}\right)$ & $\begin{array}{l}\text { Product } \\
\text { size (bp) }\end{array}$ \\
\hline \multirow[t]{2}{*}{ GAPDH } & Forward & actctggtaagtggatattgttgc & 162 \\
\hline & Reverse & ggaagatggtgatgggatttc & \\
\hline \multirow[t]{2}{*}{ BAX } & Forward & tgtttgctgatggcaacttc & 104 \\
\hline & Reverse & gatcagctcgggcactttag & \\
\hline \multirow[t]{2}{*}{ BCL-2 } & Forward & gggatgcctttgtggaacta & 138 \\
\hline & Reverse & ctcacttgtggcccaggtat & \\
\hline \multirow[t]{2}{*}{ TGF- $\beta 1$} & Forward & tgaaccggcctttcctgcttctcatg & 152 \\
\hline & Reverse & gcggaagtcaatgtacagctgccgc & \\
\hline \multirow[t]{2}{*}{ TGF- $\beta 2$} & Forward & atgcggcctattgctttaga & 185 \\
\hline & Reverse & taagctcaggaccctgctgt & \\
\hline \multirow[t]{2}{*}{ TGF- $\beta 3$} & Forward & cagggagaaaatccaggtca & 179 \\
\hline & Reverse & cctggaagggcgtctaaccaag & \\
\hline \multirow[t]{2}{*}{ TGF- $\beta R 1$} & Forward & atcacctggecttggtcctgtgg & 140 \\
\hline & Reverse & ggtcctcttcatttggcactcgatg & \\
\hline \multirow[t]{2}{*}{ TGF- $\beta R 2$} & Forward & gtctactccatggctctggt & 197 \\
\hline & Reverse & atctggatgccctggtggtt & \\
\hline \multirow[t]{2}{*}{ TGF- $\beta R 3$} & Forward & tacagagagaggtcacact & 112 \\
\hline & Reverse & gtcttcagatgccacaccag & \\
\hline
\end{tabular}

\section{Measurement of secretion of TGF- $\beta 1$ by ELISA assay}

The amount of TGF- $\beta 1$ released into the culture media supernatant of breast cancer cells was quantitated using the Quantikine human TGF- $\beta 1$ (R\&D Systems; Minneapolis, MN; USA) according to manufacturer's guidelines. After $1 \times 10^{5}$ MCF-7 and MDA-MB-231 cells were plated onto 48-well plates, cells were treated with $2 \mu \mathrm{M}$ TAM, $200 \mu \mathrm{M}$ tranilast and a combination two for $48 \mathrm{~h}$. Supernatant from conditioned medium from TAM and/ or tranilast-treated cells were analyzed for TGF- $\beta 1$ protein secretion by absorbance reading at $450 \mathrm{~nm}$. Values are expressed as secreted TGF- $\beta 1 \mathrm{pg} / \mathrm{ml} / 1 \times 10^{5}$ cells.

\section{Wound-healing assay}

The post-confluent MCF-7 and MDA-MB-231 cells were used in this experiment. Wounds with a constant diameter were made with a plastic tip $(1 \mathrm{~mm})$ and wounded monolayers were washed several times with medium to remove cell debris. For each well five areas along the length of the wound were chosen accidentally for photography under phase contrast microscope on an inverted microscope. After photography, the cells were incubated at $37^{\circ} \mathrm{C}$ in a humidified incubator containing $5 \% \mathrm{CO}_{2}$ in medium containing $2 \%$ serum in the absence or $2 \mu \mathrm{M}$ TAM, $200 \mu \mathrm{M}$ tranilast and combination of both for $48 \mathrm{~h}$ and 
allowed to migrate. Photographs of the wound areas chosen on day 0 were again taken at $48 \mathrm{~h}$. Experiments were carried out in triplicate.

\section{In vitro cell invasion assay}

Cell invasion was determined using transwell chambers made from polycarbonate membrane filters with a pore size of $8 \mu \mathrm{m}$. Transwell filters in 6-well plates were coated with matrigel, hydrated for about $2 \mathrm{~h}$ in the tissue culture incubator with $500 \mu \mathrm{l}$ serum free culture media in the bottom and $500 \mu \mathrm{l}$ in the top of the chamber. After hydration of the matrigel, $5 \times 10^{5}$ cells were plated in $500 \mu \mathrm{l} \mathrm{serum-}$ free medium on top of chamber, while $2 \mathrm{ml}$ medium $10 \%$ FCS were placed in the lower chambers. TAM at $2 \mu \mathrm{M}$, tranilast at $200 \mu \mathrm{M}$ or a combination two were added to the upper chambers. Cells without any drug were used as vehicle. After $48 \mathrm{~h}$ of incubation, the filters were removed, washed twice in PBS and fixed in 10\% formalin for 15 min. After fixing at room temperature, the chambers are rinsed in PBS and stained with $0.2 \%$ crystal violet staining solution for $30 \mathrm{~min}$. After washing the chambers by PBS, the cells at the top of the matrigel membrane were carefully removed by a number of cotton swabs. At this time all cells that remain are the ones that have invaded to the bottom side of the membrane. The number of cells was counted in 10 fields at random chosen using an inverted microscope at the $10 \times$ objective and plotted as the percentage of invading cells.

\section{Statistical analysis}

Data were expressed as the mean \pm standard error (SEM). Statistical analysis was conducted by using one-way analysis of the variance (ANOVA) and t-test. All statistical analyses were done using SPSS software 19.0 (SPSS, Inc., Chicago, IL, USA) and means were considered as statistically different for $\mathrm{P}<0.05$.

\section{Results}

\section{Cytotoxic and anti-proliferative effects of TAM and/or} tranilast on breast cancer cells

The effects of TAM and tranilast alone or in combination on percent cell survival and proliferation was evaluated by MTT and LDH leakage assays. The results show that TAM and/or tranilast exhibits the anti-proliferative effect in a dose-dependent manner in both MCF-7 and MDAMB-231 cell lines (Figures 1 and 2). The percentage of apoptotic cells in both cell lines after TAM and tranilast either alone or combined treatment was dramatically higher than in the untreated control cells. Especially, the percentage of apoptotic cells in the combined treatment was even higher than that in the treatment using the either agent alone ( $\mathrm{p}<0.001$ for each comparison). The addition of tranilast to TAM caused a synergistic antiproliferative effect on dysplastic cells and an additive growth inhibition effect in both cell lines (Figures 1 and 2). Comparing the TAM and/or tranilast effect on growth between the two cell lines yields a significantly greater effect in the MCF-7 cell line than in MDA-MB-231 cell line (Figures 1 and 2).

\section{Apoptotic effects of TAM and/or tranilast on breast cancer cells}

We investigated whether the combination of TAM and tranilast synergistically affected apoptosis of MCF-7 and MDA-MB-231 cells. To determine the effect of TAM, tranilast or combined both on apoptosis of MCF-7 and MDA-MB-231 cells, cells was treated with $2 \mu \mathrm{M}$ TAM, $200 \mu \mathrm{M}$ tranilast alone or combination two for $48 \mathrm{~h}$.

For analyzing apoptosis, several assays were employed, including TUNEL assay, DNA fragmentation, AO/EB staining and to confirm apoptosis, we performed expression of bcl-2 and bax using real-time RT-PCR.

\section{TUNEL}

The TUNEL reaction (TdT-mediated deoxy-uracil nick end labeling) is used for analyzing DNA fragmentation by labeling the $3^{\prime}-\mathrm{OH}$ ends of the DNA strand breaks. This method is based on the ability of terminal deoxynucleotidyl transferase (TdT) to attach a fluorescein-conjugated deoxyuracil to the 3'-OH end of cut DNA [21]. Presented in Figure 2 TUNEL staining clearly displayed apoptotic cells in MCF-7 and MDA-MB-231 cells treated with TAM and tranilast alone or a combination two compared to untreated control cells. The numbers of apoptotic cells were quantitated and presented as percentages (Figure $3 \mathrm{f}$ ). After treatment for $48 \mathrm{~h}, \mathrm{MCF}-7$ cells treated with TAM and tranilast alone as many as $29 \%$ and $33 \%$ of cells displayed TUNEL-positive staining, respectively, whereas $60 \%$ of the combination-treated cells were TUNELpositive. As shown in Figure 3B, TAM and tranilast also induce a significant apoptosis in MDA-MB-231 cells $(20 \%$ and $30 \%$, respectively) after $48 \mathrm{~h}$ exposure. Under the same conditions, the percentage of TUNEL-positive MDA-MB231 cells significantly increased with the combination of TAM and tranilast by $53 \%$. As expected, the results show that in both MCF-7 and MDA-MB-231 cell lines, combination treatment resulted in higher levels of apoptosis than either of them alone $(\mathrm{p}<0.01)$. In addition, TUNEL staining revealed an increased number of apoptotic cells in MCF-7 cells (Figure 3A) compared with MDA-MB231 cells (Figure 3B).

\section{Acridine orange/ethidium bromide (AO/EB) staining}

Cell death was divided into two types, necrosis and apoptosis. Necrosis causes inflammation while apoptosis does not. Induction of apoptosis in tumor cells has already been used as an important indicator to detect the ability of chemotherapeutic drugs to inhibit tumor growth [22]. 

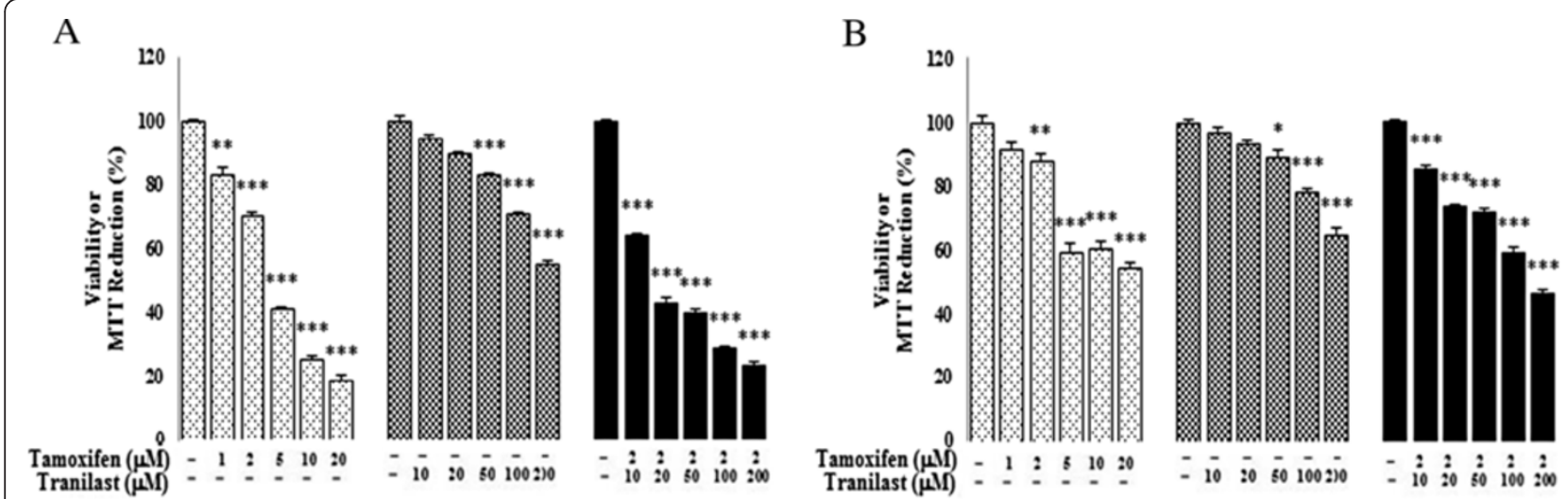

Figure 1 The effects of TAM and/or tranilast on viability in MCF-7 (A) and MDA-MB-231 (B) cells. Cells were treated with TAM, tranilast and combination both for $48 \mathrm{~h}$. Control wells were treated with equivalent amount of media alone. Treatment with TAM and tranilast combined significantly decreased the viability compared with TAM or tranilast alone. The results showed the mean and SE from triplicated experiments. $\left({ }^{*} p<0.05 ;{ }^{* *} p<0.01{ }^{* * *} p<0.001\right.$ compared with control).

Staining of apoptotic cells with fluorescent dyes such as $\mathrm{AO}$ and $\mathrm{EB}$ is considered the correct method for evaluating the changed nuclear morphology [23]. AO permeates all cells and the nuclei become green whereas EB is only taken up by cells that their cytoplasmic membrane integrity is lost, and their nuclei are stained red. EB also dominates over AO. Thus, live cells will show a normal green nucleus. Early apoptotic cells should give bright green nucleus with condensed or fragmented chromatin. Late apoptotic cells display condensed and fragmented orange chromatin and necrotic cells have a structurally normal orange nucleus [24].

The type of cell death induced by TAM, tranilast and combination of both studied by fluorescent staining for assessment of morphological changes. The Figure 4 exhibited morphological changes of apoptosis including cell shrinkage and chromatin condensation as compared to control cells. The live, apoptotic and necrotic and cells were monitored under the fluorescent microscope. From the results of Figure 4 we found that in MCF-7 cells, live cells were seen in the control group, both early and late apoptotic cells are seen in the presence of $2 \mu \mathrm{M}$ TAM, while late apoptotic cells are obvious in the presence of $200 \mu \mathrm{M}$ of tranilast and in the presence of combined treatment, the nearly all cells are late apoptotic cells (Figure 4A).

In MDA-MB-231 cells, live cells with normal morphology were seen in the control group, whereas early apoptotic cells occurred in the group with $2 \mu \mathrm{M}$ TAM, early and late apoptotic cells were seen when $200 \mu \mathrm{M}$ of tranilast and in the presence of combination both a number of cells in late stage, few cells also in early stage (Figure 4B). These morphological changes suggest that combination treatment significantly increased apoptosis in both MCF-7 and MDA-MB-231 cells.
A

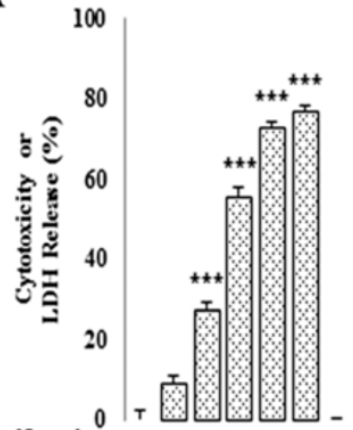

B

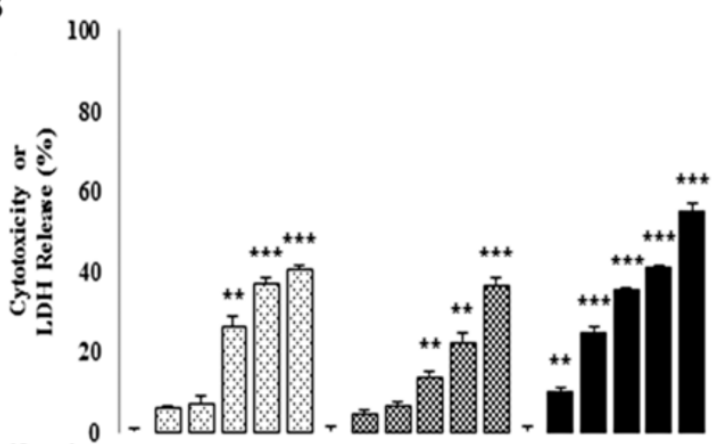

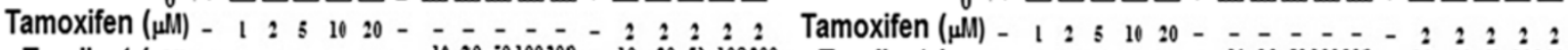
Tranilast $(\mu \mathrm{M})$ - - - - $102030100200-1020$ 5) 100200 Tranilast $(\mu \mathrm{M})-\ldots-2-2-102030100200-1020$ 5) 100200

Figure 2 TAM combined with tranilast additively inhibits survival of MCF-7 (A) and MDA-MB-231 (B) cells at 48 h. Shown are the mean values of three experiments \pm SE. $p$ values were determined using one-way ANOVA $\left({ }^{*} p<0.05,{ }^{* *} p<0.01\right.$, ${ }^{* *} p<0.001$ compared with control). 


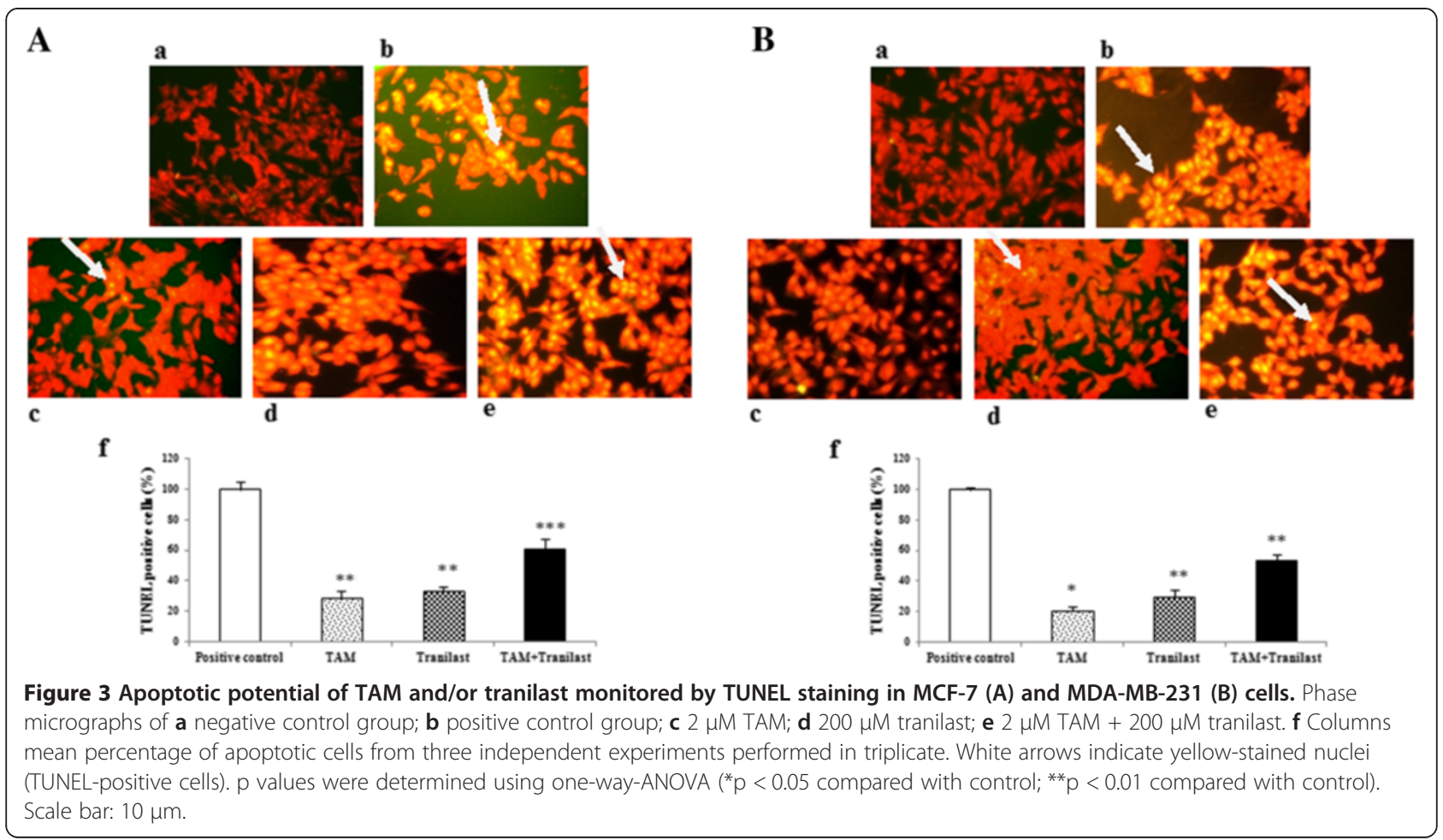

\section{DNA fragmentation}

This procedure is based on internucleosomal DNA cleavage, a characteristic biochemical hallmark of the apoptotic mode of cell death.

Apoptosis of MCF-7 and MDA-MB-231 cells also detected by analysis of DNA fragmentation on agarose gel, a classical method of detecting the DNA ladders that accompany late apoptosis, in vitro. After treatment with $2 \mu \mathrm{M}$
TAM, $200 \mu \mathrm{M}$ tranilast and combination both for $48 \mathrm{~h}$, the DNA extracted from cells was electrophoresed on $2 \%$ agarose gels. As shown in Figure 5, fragmented DNA was barely detectable. However, substantial amounts of low-molecularweight DNA were present; indicating that either a small subset of cells had undergone internucleosomal DNA digestion or that only a fraction of each cell's DNA had become fragmented. Although DNA fragmentation has been
A
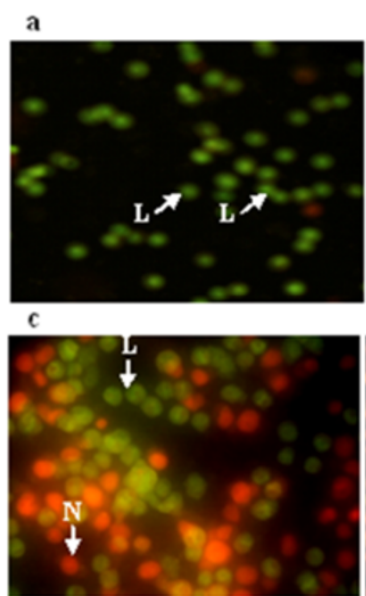

b

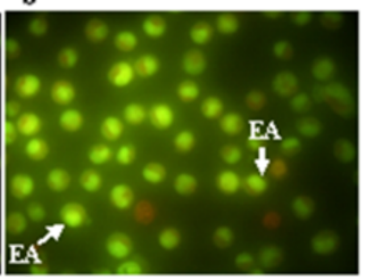
d

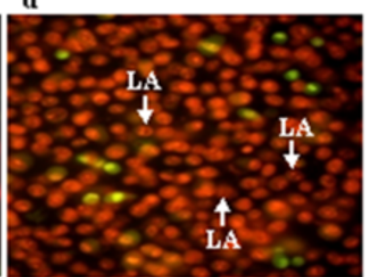

B

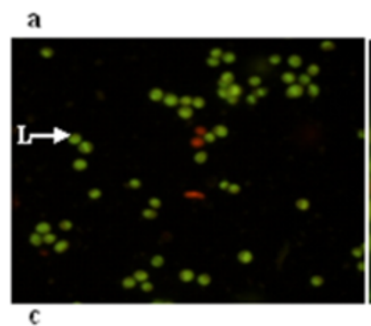

b
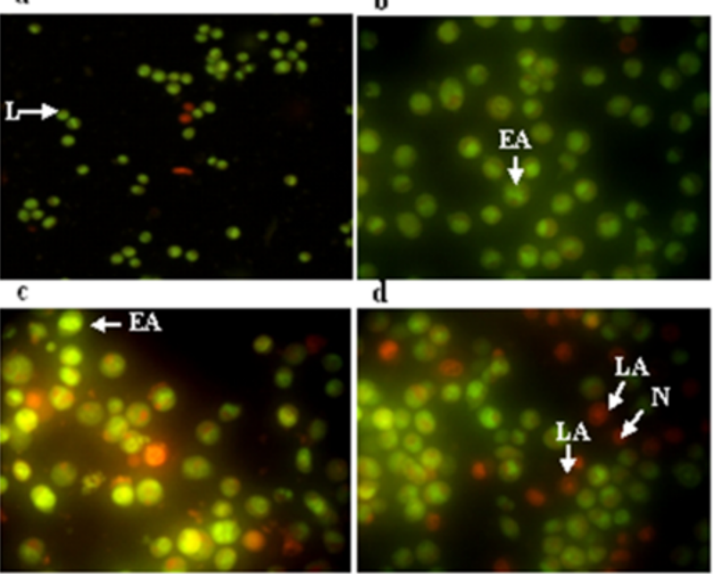
d

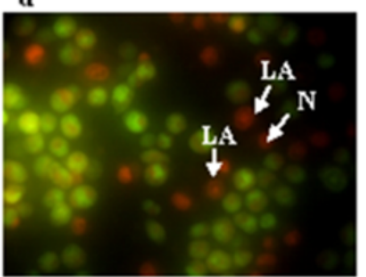

Figure 4 MCF-7 (A) and MDA-MB-231 (B) cells were stained by AO/EB and observed under fluorescence microscope: a control group; $b$ in the presence of $2 \mu \mathrm{M}$ TAM; $c$ in the presence of $200 \mu \mathrm{M}$ tranilast; $d$ in the presence of in combination both. Green live cells show normal morphology; green early apoptotic cells show nuclear margination and chromatin condensation. Late orange apoptotic cells showed fragmented chromatin and apoptotic bodies. Scale bar: $10 \mu \mathrm{m} . \mathrm{L}=$ live cells, $\mathrm{A}=$ early apoptotic cells, $\mathrm{LA}=$ late apoptotic cells, $\mathrm{N}=$ necrotic cells. 


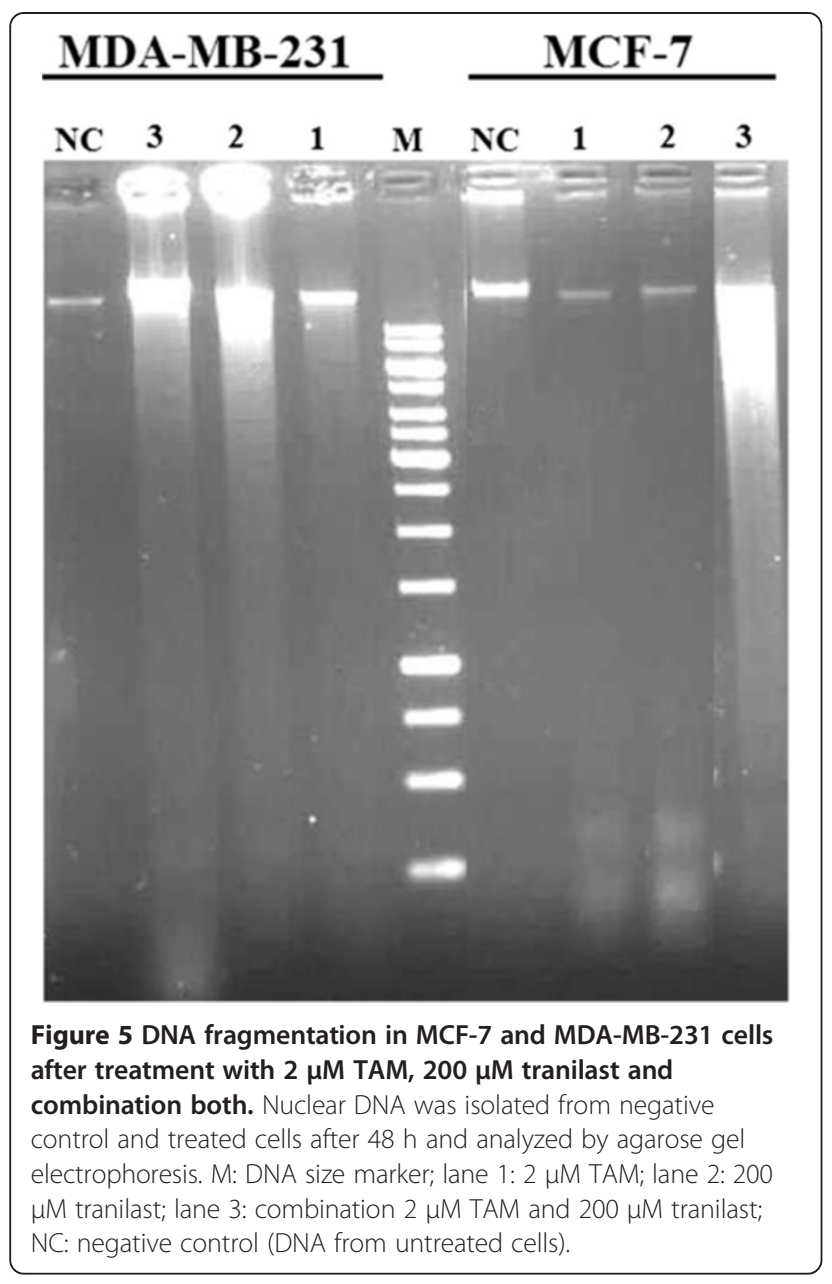

A

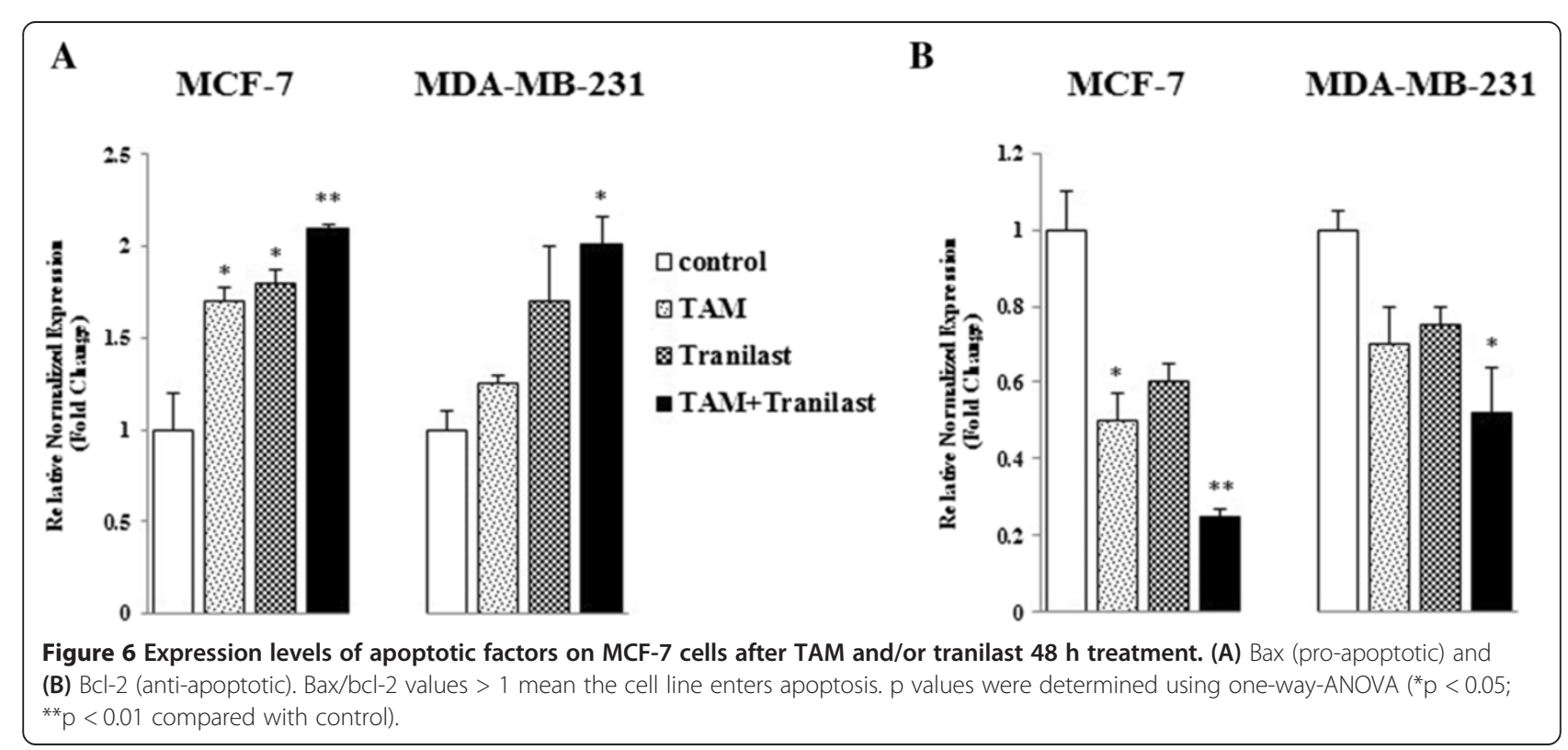

seen in many cell types and is generally considered the biochemical hallmark of apoptosis, it may be delayed, partial or absent in some cell types or experimental conditions. Therefore, it seems that treatment of MCF-7 and MDAMB-231 cells with these doses not leads to significant DNA fragmentation (Figure 5).

Previous studies show also that treatment of epithelial cancer cell lines with a specific DNA-damaging agent will produce high molecular weight DNA fragmentation in the absence of nucleosomal laddering [25,26]. In Addition, some apoptosis studies fail to exhibit the DNA fragmentation pattern in the mammary carcinoma cells $[21,27]$.

\section{Levels of bax and bcl-2 mRNA expression}

To further investigate the apoptotic action of these two agents, we used quantitative real-time PCR to study the influence of them on bcl-2 and bax mRNA expression. In many human cancers, the anti-apoptotic bcl-2 proteins are overexpressed, or the pro-apoptotic proteins like bax, have reduced expression [28]. This results in resistance to a wide variety of cell death stimuli including chemotherapeutic drugs [29].

Results of real-time quantitative PCR appeared to show down-regulation of bcl- 2 and upregulation of bax expression at 48 hours treatment (Figure 6A, B). Expression of bcl-2 and bax was targets for TAM and tranilast as a single or combination and after $48 \mathrm{~h}$ exposure, a significant reduction of bcl-2 and induction of bax mRNA expression was observed. Bax to bcl-2 mRNA ratio was determined for MCF-7 cells: 3.4 in TAM treatment, 3.0 in tranilast treatment and 8.4 in combined group and for MDA-MB231 cells: 1.7 in TAM treatment, 2.2 in tranilast treatment 
and 3.8 in combination. Hence, the ratio of pro-apoptotic to the anti-apoptotic was altered in favor of apoptosis (Figure 6). Thus, the results suggest that an up-regulation of bax and the corresponding down-regulation of bcl-2 mRNAs observed in this study may be one of the critical mechanisms through which TAM and/or tranilast induces apoptosis in breast cancer cells.

\section{Effects of TAM and/or tranilast treatment on mRNA level} of TGF- $\beta$ ligands and receptors in breast cancer cells Exposure of cell cultures to TAM and tranilast either alone or in combination for $48 \mathrm{~h}$ decreased expression of TGF- $\beta 1,-\beta 2,-\beta 3$ and T $\beta$ RI, $\beta$ RII mRNA. TGF- $\beta 1$ mRNA levels were high but $48 \mathrm{~h}$ after TAM, tranilast or combined treatment they were diminished approximately a 30\% $(\mathrm{p}<0.05), 70 \%(\mathrm{p}<0.01)$ and $92 \%(\mathrm{p}<$ $0.001)$ in MCF-7 cells and $15 \%, 40 \%$ and $60 \%(\mathrm{p}<0.01)$ in MDA-MB-231 cells (Figure 7). At the same time,
mRNA expression of TGF- $\beta 2$ in treatment with TAM or tranilast was down-regulated by $25 \%$ or $55 \%(\mathrm{p}<0.05)$ in MCF-7 and $15 \%$ or $45 \%(\mathrm{p}<0.05)$ in MDA-MB-231 respectively, while mRNA expression levels were decreased by approximately 10 -fold in the presence of TAM plus tranilast $(\mathrm{p}<0.01)$ in MCF-7 and 2-fold in MDA-MB231 cells $(\mathrm{p}<0.05)$ (Figure 7$)$. Incubation of the cells for $48 \mathrm{~h}$ with TAM, tranilast or both down-regulate the mRNA encoding TGF- $\beta 3$ by $40 \%, 60 \%(\mathrm{p}<0.05)$ and $80 \%$ in MCF-7 cells; and 10\%, 30\% and 65\% in MDAMB-231 cells respectively (Figure 7). Expression T $\beta R I$ in TAM, tranilast or a combination two groups was decreased by approximately $2.5(\mathrm{p}<0.05), 5(\mathrm{p}<0.05)$ and 25 -fold $(\mathrm{p}<0.01)$ by MCF-7 cells, and $15 \%, 50 \%$ ( $<<$ $0.05)$ and $65 \%(\mathrm{p}<0.05)$ by MDA-MB-231 cells, respectively. Incubation of the cultured cell lines with TAM, tranilast or two drug decreased mRNA level encoding T $\beta$ RII by $50 \%(\mathrm{p}<0.01), 55 \%(\mathrm{p}<0.05)$ and $87 \%(\mathrm{p}<$

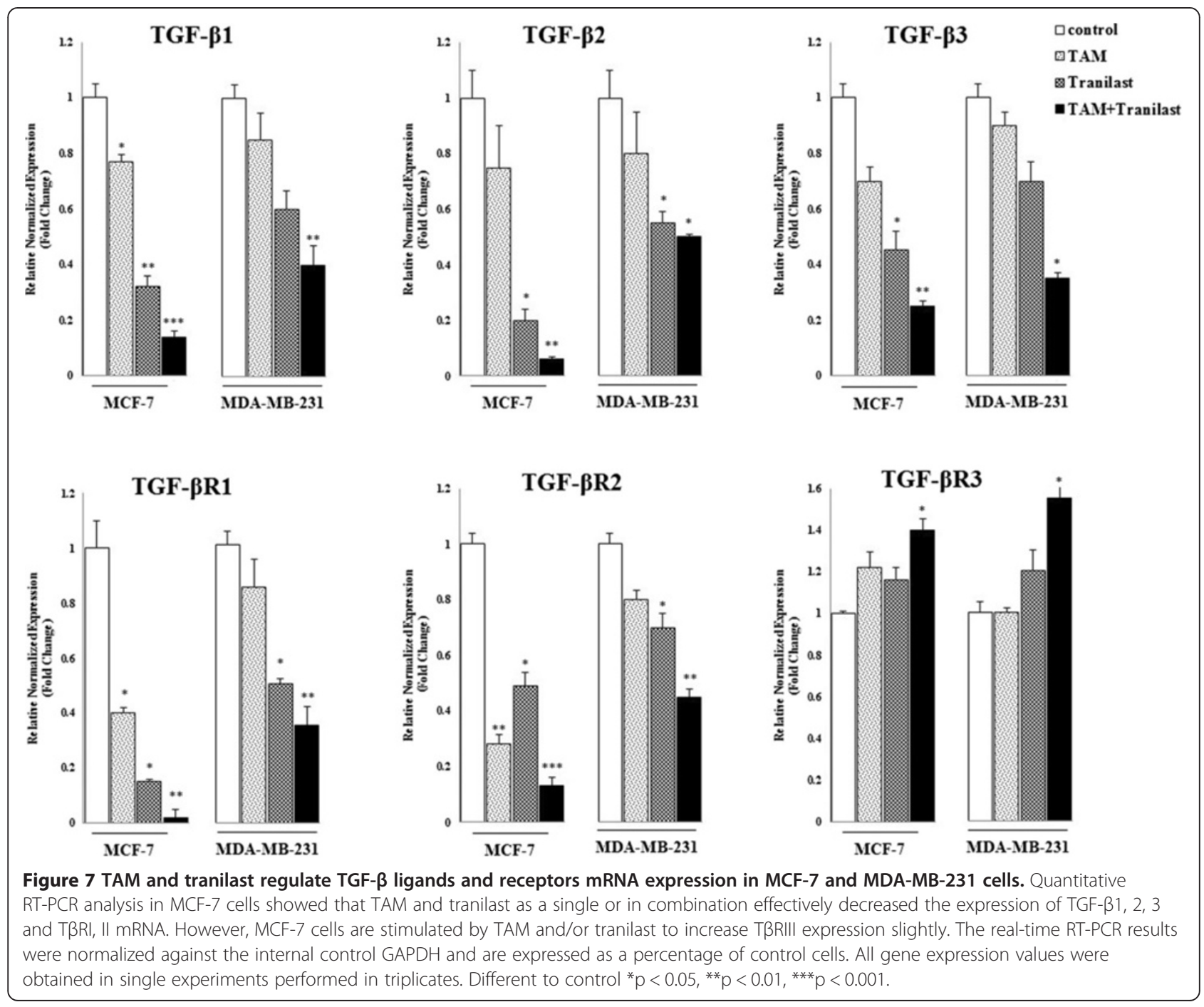


$0.001)$ in MCF-7 and 15\%, 30\% ( $<<0.05)$ and 55\% ( $<$ 0.01 ) in MDA-MB-231 cells, respectively (Figure 7). However, Forty eight hours after TAM, tranilast or combined treatment the type III receptor mRNA levels were increased by about 20\%, 50\%, and 75\% $(\mathrm{p}<0.05)$ in MCF-7 and without difference, $20 \%$ and $55 \%(\mathrm{p}<0.05)$ in MDA-MB-231 cells, respectively compared with vehicle cells (Figure 7).

\section{Effect of TAM and/or tranilast on TGF- $\beta 1$ secretion in MCF-7 and MDA-MB-231 breast cancer cells}

To evaluate the effects of TAM and/or tranilast on TGF- $\beta 1$ production from MCF-7 and MDA-MB-231 cells, we measured using ELISA kit secreted TGF- $\beta 1$ protein level in the culture medium on cells treated with drugs alone or combination of both. We found that treating MCF-7 or MDA-MB-231 cells with TAM and tranilast as a single treatment for $48 \mathrm{~h}$ significantly decreased TGF- $\beta 1$ secretion from breast cancer cell lines, compared to control $(\mathrm{p}=0.21$ for TAM and $\mathrm{p}<0.01$ for tranilast in MCF-7; $\mathrm{p}=0.26$ for TAM and $\mathrm{p}<0.05$ for tranilast in MDA-MB231 cells). The minimum protein levels were observed as an effect of combination treatment $(\mathrm{p}<0.01$ in MCF-7 and $\mathrm{p}<0.001$ in MDA-MB-231 cells). These inhibitory effects also were higher in MCF-7 cells (Figure 8A) than in MDA-MB-231 cells (Figure 8B).

\section{Effects of TAM and/or tranilast on cell migration} and invasion

To evaluate the effects of TAM and tranilast as a single or combined treatment on cell migration, we performed wound (scratch) and transwell invasion assays in MCF-7 and MDA-MB-231 cells. After $48 \mathrm{~h}$ treatment, cells in the control group efficiently spread into the wound area to such an extent that the wound boundary was not apparent, while only some cells in TAM or tranilast treated group spread forward in MCF-7 and MDA-MB-231 cells. The cell migration in combination group was lower than either drugs alone. (Figure 9A, B). In migration assay using a transwell system, migration was also decreased significantly with TAM or tranilast treatment. Combination TAM with tranilast decreased cell invasive ability of MCF-7 and MDA-MB-231 cells by 75\% ( $\mathrm{p}<$ $0.001)$ and $60 \%(\mathrm{p}<0.001)$, respectively (Figure 10A, B) compared with the control.

\section{Discussion}

This study indicates that the effects of TAM with combination tranilast may be enhanced, which shows the mixture of TAM with tranilast produced a significant additive cytotoxic effect in both cell lines. Our data also demonstrated that TAM and tranilast inhibited MCF-7 and MDA-MB-231 cells proliferation by inducing apoptosis and the enhanced apoptosis may account for the synergistic inhibition of the combination treatment.

Disabling of apoptosis is a central event in tumorigenesis, and most chemotherapeutic drugs require functioning apoptotic pathways [2]. Estrogen results in a general upregulation of genes regulating cell proliferation and survival and the down-regulation of genes with anti-proliferative or pro-apoptotic activity and the final resulting in growth stimulation and apoptosis suppression [30]. Therefore, antiestrogens are able to decrease cancer cell proliferation and induce cell death signaling pathways [31].
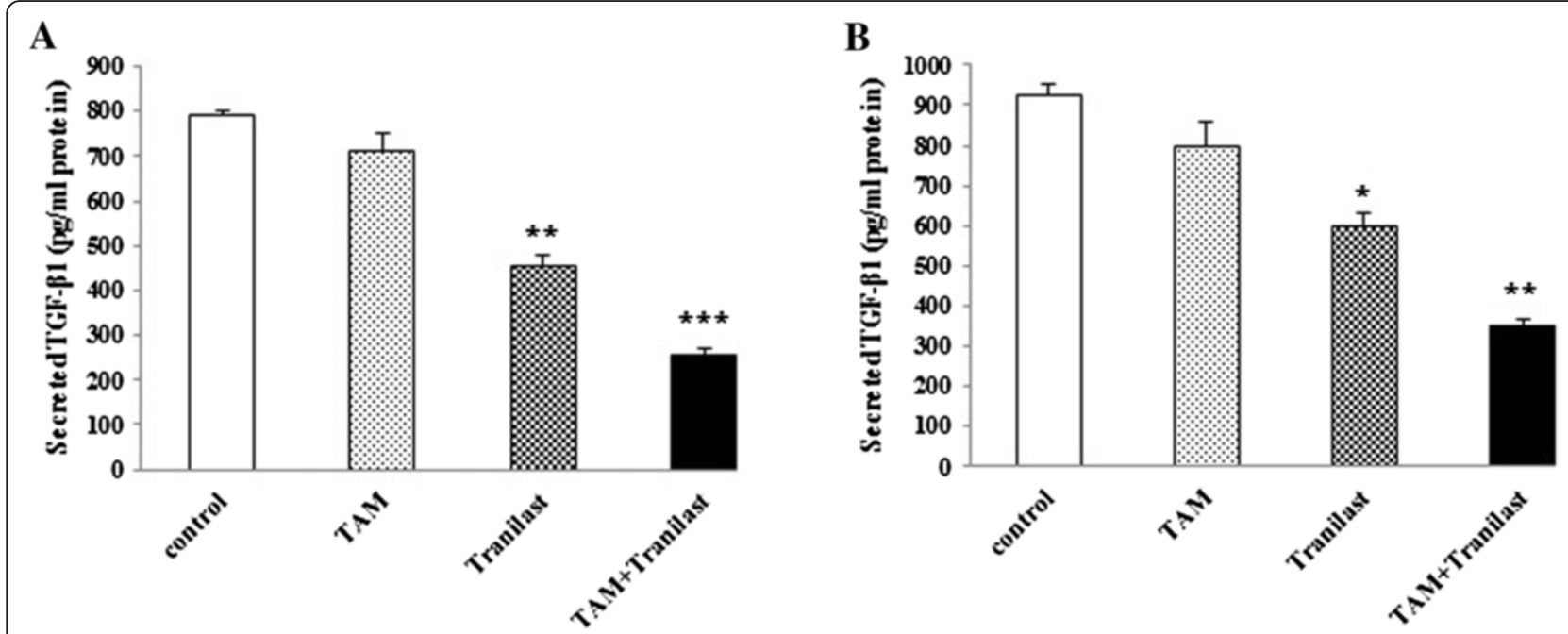

Figure 8 Tranilast and TAM regulate the extracellular TGF- $\beta 1$ protein secreted from cultured human breast cancer cells. MCF-7 and MDA-MB-231 cells were cultured without drugs (control) or in the presence of $2 \mu \mathrm{M}$ TAM, $200 \mu \mathrm{M}$ tranilast or a combination two for $48 \mathrm{~h}$. Results represent at least two independent experiments \pm SEM. (A) TGF- $\beta 1$ protein levels in medium from MCF-7 cells; (B) TGF- $\beta 1$ protein levels in medium from MDA-MB-231 cells $\left({ }^{*} p<0.05,{ }^{* *} p<0.01,{ }^{* * *} p<0.001\right)$. 


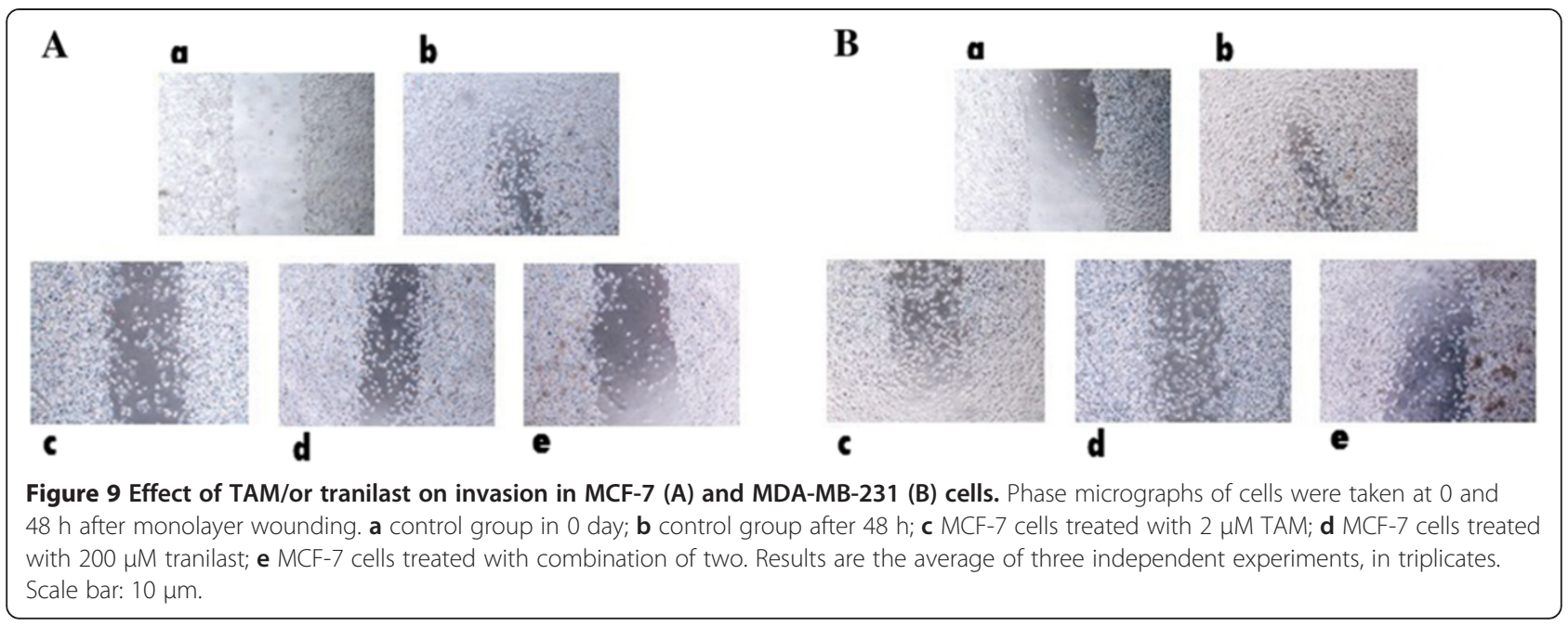

Consequently, tamoxifen treatment induces cell-cycle arrest leads to an accumulation of cancer cells in G0/G1 phase of the cell cycle [32] and induce apoptosis of breast cancer cells [33]. Morphological changes occur in apoptotic cells provide the most important means of diagnosing apoptosis, which the chromatin condenses and collapses into patches, followed by nuclear fragmentation and produce apoptotic bodies [34]. The Bcl-2 family of proteins, with pro- and anti-apoptotic members, regulates apoptosis during mammary gland development and mammary tumorigenesis [35]. It has been determined that both anti-apoptotic bcl-2 and proapoptotic bax contribute to mammary apoptosis [36] as well the bcl-2 gene is overexpressed in breast cancer cells [37].

In this work, synergistic effect of combination TAM and tranilast on induction apoptosis in breast cancer in vitro examined using some methods and changes in apoptotic cells evaluated. TAM and/or tranilast induced characteristic morphological modifications associated with apoptosis, including condensation of chromatin and DNA cleavage, as well expression of apoptosis regulators, bax and bcl-2 assessed and confirmed. We have demonstrated that the combination of TAM and tranilast resulted in a synergistic effect on both growth inhibition and apoptosis induction.

Studies have revealed that TAM is also effective in treatment of ER-negative tumors including breast [38]. The apoptosis induced by TAM is not reversible by addition of estrogens, telling that ER-independent induction of apoptosis could be a dominant mechanism of action in ER-negative breast tumors [39]. On the other side, inhibition of breast cancer growth by tamoxifen appears to be mediated by TGF- $\beta$ signaling pathway [20]. Tamoxifen implements its effects both directly through the promotion of apoptosis and inhibition of mitosis, and indirectly through the TGF- $\beta$. It is found that changed expression of growth factors, among them TGF- $\beta$, is crucial for carcinogenesis [40]. TGF- $\beta$ plays pivotal role in breast cancer. Some studies show that TGF- $\beta$ is a potent inhibitor of primary mammary epithelial cells and breast cancer cell lines and reduced levels of TGF- $\beta$ signaling are observed in several cancers $[41,42]$. Conversely, a large number of reports indicate that TGF- $\beta$ turn into a promoter of progression in advanced tumor stages $[43,44]$ by stimulation of angiogenesis, extracellular matrix degradation and metastasis [45]. Studies have shown a causal association between TGF- $\beta$ and motility, invasiveness and metastasis [46] also survival and malignancy of human breast carcinoma cells [47]. Expression of TGF- $\beta 1, \beta-2$, and $\beta-3$ mRNAs has been detected in human breast cancer cells [48]. Moreover, autocrine/paracrine TGF- $\beta$ and its downstream Smad signaling play a survival role in breast cancer cells also EpithelialMesenchymal Transition (EMT) and lead to acquired tamoxifen resistance [49].

In this study tranilast with TAM down-regulated the expression of TGF- $\beta 1, \beta-2$, and $\beta-3$ also T $\beta R I$ and T $\beta R I I$ from breast cancer cells. T $\beta$ RIII or betaglycan is a suppressor of breast cancer progression and that, when TRRIII expression is restored, invasion, angiogenesis, and metastasis is inhibited in vivo [50]. In this study, tranilast and TAM increased the expression of T $\beta$ RIII slightly. Despite these uncertainties, it has become apparent that TGF$\beta$ gains a growth-promoting role and treatments that block TGF- $\beta$ signaling have shown some efficacy in clinical trials [51].

Recently, there has been an increasing interest in evaluating combining chemotherapeutic drugs with other substances [52-55] for achieving better treatment with less toxicity in breast cancer. In this regard, we had chosen tranilast as an adjuvant to TAM in breast cancer therapy. 


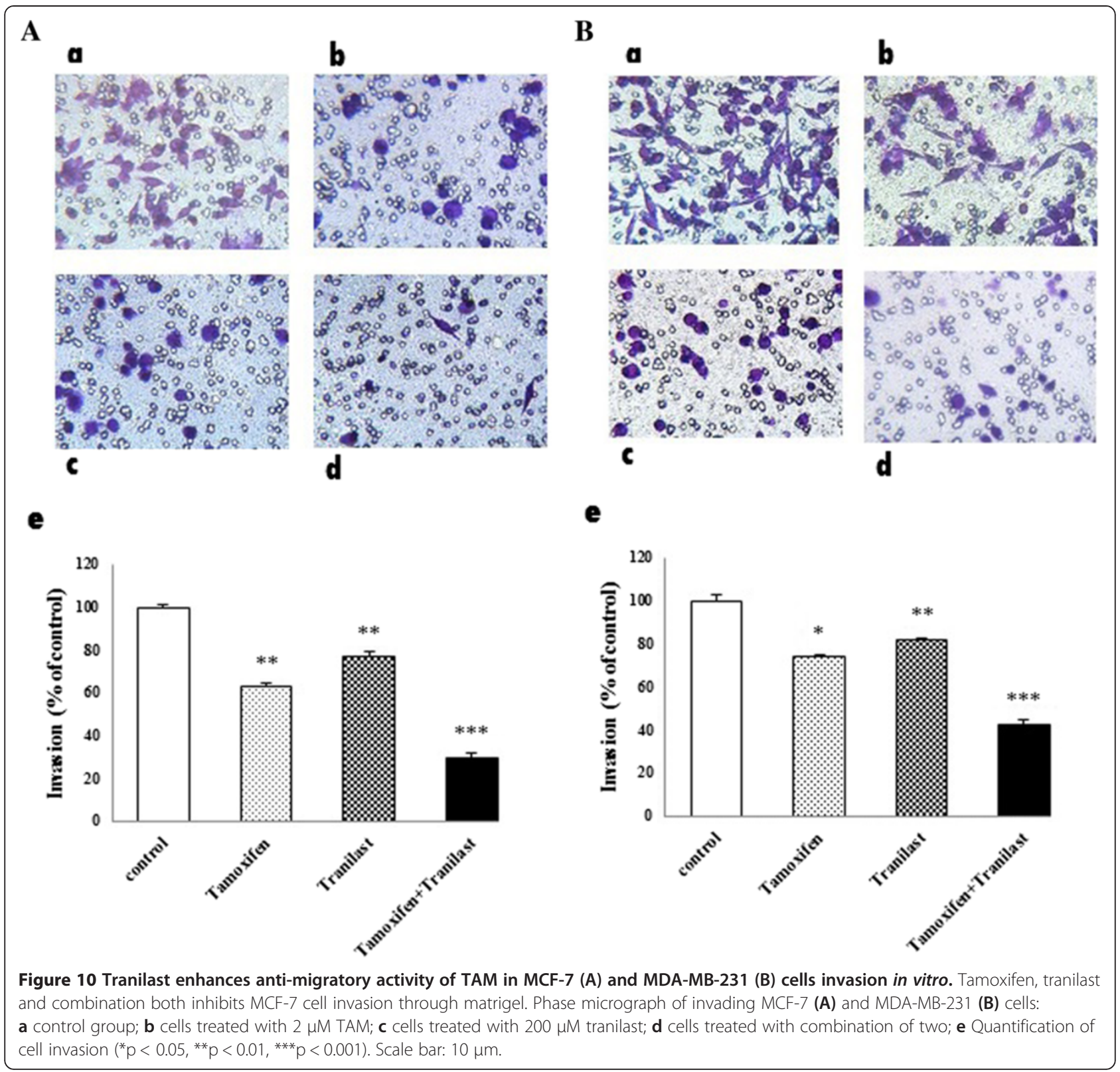

Tranilast revealed no significant side effects even when administered for time-consuming periods and several reports showed that tranilast inhibits the proliferation of several cancer cell types including breast [56-59]. The inhibitory mechanisms have been elucidated as regards tranilast function, including its role in inhibiting and antagonizing the TGF- $\beta$ pathway [60].

In the present study we show, tranilast as a single or in combination with TAM can regulate TGF- $\beta$ isoforms and receptors gene expression and TGF- $\beta 1$ protein secretion from human breast cancer cells. In addition, we demonstrate that tranilast and/or TAM inhibit migration and invasion of MCF-7 and MDAMB-231 cells and these results could explain the beneficial effects of this combination in management of breast cancer. These results suggest that the additive effect between TAM and tranilast in inhibiting breast cancer may in part reflect the ability of both drugs to modulate and suppress TGF- $\beta$ in breast cancer cells.

The anti-tumor effects observed here occurred at concentrations of tranilast that may well be achieved in vivo. If the results are confirmed in vivo, they may be significant clinically. Future researches on the detailed mechanisms of these using tranilast and tamoxifen will facilitate the understanding of the synergistic effects of these drugs on apoptosis as well TGF- $\beta$ pathway. 


\section{Conclusions}

These results suggest that tamoxifen plus tranilast could be a promising combination therapy for future clinical trials in breast cancer patients. However further studies are also needed to investigate the expression of TGF- $\beta$ pathway components in breast cancer contributes to the regulation of metastasis. Nonetheless, our study suggests that TGF- $\beta$ pathway may be targeted for the inhibition of invasion in breast cancer cells. In a line, we believe that the present data may lead to new therapeutic options for breast cancer.

\section{Competing interests}

The authors declare that they have no competing interests.

\section{Authors' contributions}

SD performed the experiments and drafted the manuscript; AGH designed research and performed the statistical analysis. Both authors read and approved the final draft of the manuscript.

\section{Acknowledgments}

The authors thank the Medical Biology Research Center and Fertility and Infertility Research Center (FIRC) for facility support.

\section{Author details}

${ }^{1}$ Department of biology, Faculty of science, Razi University, Kermanshah, Iran. ${ }^{2}$ Fertility and Infertility Research Center, Kermanshah University of Medical Sciences, Kermanshah, Iran.

Received: 7 July 2013 Accepted: 14 October 2013

Published: 21 October 2013

\section{References}

1. Hengartner MO: The biochemistry of apoptosis. Nature 2000, 407:770-776.

2. Johnstone RW, Ruefli AA, Lowe SW: Apoptosis. A Link between cancer genetics and chemotherapy. Cell 2002, 108:153-164.

3. Mehlen P, Puisieux A: Metastasis: a question of life or death Nat Rev Cancer 2006, 6:449-458.

4. Johansen AM: Breast cancer chemoprevention: a review of selective estrogen receptor modulators. Clin J Oncol Nurs 2005, 9:317-320.

5. Higgins MJ, Baselga J: Targeted therapies for breast cancer. Journal of Clinical Invest 2011, 121:3797-3803.

6. Roberts CG, Millar EK, OToole SA, McNeil CM, Lehrbach GM, Pinese M, et al: Identification of PUMA as an estrogen target gene that mediates the apoptotic response to tamoxifen in human breast cancer cells and predicts patient outcome and tamoxifen responsiveness in breast cancer. Oncogene 2011, 30:3186-3197.

7. Massague J: TGF-beta signal transduction. Annu Rev Biochem 1998, 67:753-791.

8. Hata A, Shi Y, Massague J: TGF-beta signaling and cancer: structural and functional consequences of mutations in Smads. Mol Med Today 1998, 4:257-262.

9. Fleisch MC, Maxwell CA, Barcellos-Hoff MH: The pleiotropic roles of transforming growth factor beta in homeostasis and carcinogenesis of endocrine organs. Endocr Relat Cancer 2006, 13:379-400.

10. Pierce DF Jr, Johnson MD, Matsui Y, Robinson SD, Gold LI, Purchio AF, et al: Inhibition of mammary duct development but not alveolar outgrowth during pregnancy in transgenic mice expressing active TGF-beta 1. Genes Dev 1993, 7:2308-2317.

11. Elliott RL, Blobe GC: Role of transforming growth factor Beta in human cancer. J Clin Oncol 2005, 23:2078-2093.

12. Walker RA, Dearing SJ: Transforming growth factor $\beta 1$ in ductal carcinoma in situ and invasive carcinomas of the breast. Eur J Cancer 1992, 28:641-644.

13. Azuma H, Banno K, Yoshimura T: Pharmacological properties of N-(3', 4'dimethoxycinnamonyl) anthranilic acid, a new antiatopic agent. Br J Pharmacol 1976, 58:483-488.

14. Suzawa H, Kikuchi S, Arai N, Koda A: The mechanism involved in the inhibitory action of tranilast on collagen biosynthesis of keloid fibroblasts. Jpn J Pharmacol 1992, 60:91-96
15. Miyazawa K, Kikuchi S, Fukuyama J, Hamano S, Ujiie A: Inhibition of PDGFand TGF-beta 1-induced collagen synthesis, migration and proliferation by tranilast in vascular smooth muscle cells from spontaneously hypertensive rats. Atherosclerosis 1995, 118:213-221.

16. Ikeda $\mathrm{H}$, Inao M, Fujiwara K: Inhibitory effect of tranilast on activation and transforming growth factor beta 1 expression in cultured rat stellate cells. Biochem Biophys Res Commun 1996, 227:322-327.

17. Fukuyama J, Miyazawa K, Hamano S, Ujiie A: Inhibitory effects of tranilast on proliferation, migration, and collagen synthesis of human vascular smooth muscle cells. Can J Physiol Pharmacol 1996, 74:80-84

18. Ochiai H, Ochiai Y, Chihara E: Tranilast inhibits TGF- $\beta 1$ secretion without affecting its mRNA levels in conjunctival cells. Kobe J Med Sei 2001, 47:203-209.

19. Platten M, Wick W, Wischhusen J, Weller M: N-[3, 4- dimethoxycinnamoyl]anthranilic acid (tranilast) suppresses microglial inducible nitric oxide synthase (iNOS) expression and activity induced by interferon-gamma (IFN-gamma). Br J Pharmacol 2011, 134:1279-1284.

20. Buck MB, Pfizenmaier $K$, Knabbe $C$ : Antiestrogens induce growth inhibition by sequential activation of p38 mitogen-activated protein kinase and transforming growth factor-beta pathways in human breast cancer cells. Mol Endocrinol 2004, 18:1643-1657.

21. Gaverieli Y, Sherman Y, Ben-Sasson SA: Identification of programmed cell death in situ via specific labeling of nuclear DNA fragmentation. J Cell Biol 1992, 119:493-501.

22. Zhang T, Chen X, Qu L, Wu J, Cui R, Zhao Y: Chrysin and its phosphate ester inhibit cell proliferation and induce apoptosis in Hela cells. Bioorg Med Chem 2004, 12:6097-6105.

23. Savitskiy VP, Shman T, Potapnev MP: Comparative measurament of spontaneous apoptosis in pediatric acute leukemia by different techniques. Cytometry 2003, 56:16-22

24. Renvoize C, Biola A, Pallardy M, Breard J: Apoptosis: identification of dying cell. Cell Biol Toxicol 1998, 14:111-120.

25. Ayusawa D, Arai H, Wataya $Y$, Seno T: A specialized form of chromosomal DNA degradation induced by thymidylate stress in mouse sel FM3A. Mutat Res 1988, 200:221-230

26. Canman CE, Tang HY, Normolle DP, Lawrence TS, Maybaum J: Variation in patients of DNA damage induced in human colorectal tumor cells by 5 fluorodeoxyuridine: Implications for mechanism of recistance and cytotoxicity. Proc Natl Acad Sci USA 1992, 89:10474-10478.

27. Oberhammer F, Wilson JW, Dive C, Morris ID, Hickman JA, Wakeling AE, Walker PR, Sikorska M: Apoptotic death in epithelial cells: cleavage of DNA to $300 \mathrm{and} /$ or $50 \mathrm{~kb}$ fragments prior to or in the absence of internucleosomal fragmentation. EMBO J 1993, 12:3679-3684.

28. Reed J, Miyashita T, Takayama S, Wang HG, Sato T, Krajewski S, AimeSempe C, Bodrug S, Kitada S, Hanada M: Bcl-2 family proteins: regulators of cell death involved in the pathogenesis of cancer and resistance to theraphy. J Cell Biochem 1996, 60:23-32.

29. Adam JM, Cory S: The bcl-2 protein family: Arbiters of cell survival. Science 1998, 281:1322-1326.

30. Frasor J, Danes JM, Komm B, Chang KC, Lyttle CR, Katzenellenbogen BS: Profiling of estrogen up- and down-regulated gene expression in human breast cancer cells: insights into gene networks and pathways underlying estrogenic control of proliferation and cell phenotype. Endocrinology 2003, 144:4562-4574.

31. Renoir JM, Bouclier C, Seguin A, Marsaud V, Sola B: Antioestrogenmediated cell cycle arrest and apoptosis induction in breast cancer and multiple myeloma cells. J Mol Endocrinol 2008, 40:101-112.

32. Thiantanawat A, Long BJ, Brodie AM: Signaling pathways of apoptosis activated by aromatase inhibitors and antiestrogens. Cancer Res 2003, 63:8037-8050.

33. Maccarrone M, Fantini C, Ranalli M, Melino G, Agro AF: Activation of nitric oxide synthase is involved in tamoxifen-induced apoptosis of human erythroleukemia K562 cells. FEBS Lett 1998, 434:421-424.

34. Stewart BW: Mechanisms of apoptosis: integration of genetic, biochemical, and cellular indicators. Journal of National Cancer Institute 1994, 86:1286-1296.

35. Adams JM, Cory S: Bcl-2-regulated apoptosis: mechanism and therapeutic potential. Curr Opin Immunol 2007, 19:488-496.

36. Metcalfe AD, Gilmore A, Klinowska T, Oliver J, Valentijn AJ, Brown R, Ross A MacGregor G, Hickman JA, Streuli CH: Developmental regulation of bcl-2 family protein expression in the involuting mammary gland. J Cell Sci 1999, 112:1771-1783. 
37. Zhang GJ, Kimijima I, Onda M, Kanno M, Sato H, Watanabe T, Tsuchiya A, Abe R, Takenoshita S: Tamoxifen-induced apoptosis in breast cancer cells related to down regulation of bcl-2, but not bax and $\mathrm{bcl}-\mathrm{XL}$, without alteration of p53 protein levels. Clin Cancer Res 1999, 5:2971-2977.

38. Salami S, Karami-Tehrani F: Biochemical studies of apoptosis induced by tamoxifen in estrogen receptor positive and negative breast cancer cell lines. Clin Biochem 2003, 36:247-253.

39. Weng SC, Kashida Y, Kulp SK, Wang D, Brueggemeier RW, et al: Sensitizing estrogen receptor-negative breast cancer cells to tamoxifen with OSU03012, a novel celecoxib-derived phosphoinositide-dependent protein kinase-1/Akt signaling inhibitor. Mol Cancer Ther 2008, 7:800-808.

40. Colletta AA, Wakefield LM, Howell FV, Danielpour D, Baum M, Sporn MB: The growth inhibition of human breast cancer cells by a novel syntheticbprogestin involves the induction of transforming growth factor beta. J Clin Invest 1991, 87:277-283.

41. Mulder KM: Role of Ras and Mapks in TGF beta signaling. Cytokine Growth Factor Rev 2000, 11:23-35.

42. Basolo F, Fiore L, Ciardiello F, Calvo S, Fontanini G, Conaldi PG, Toniolo A: Response of normal and oncogenetransformed human mammary epithelial cells to transforming growth factor beta 1 (TGF-beta 1): lack of growth-inhibitory effect on cells expressing the simian virus 40 large-T antigen. Int J Cancer 1994, 56:736-742.

43. Gorsch SM, Memoli VA, Stukel TA, Gold LI, Arrick BA: Immunohistochemical staining for transforming growth factor $\beta 1$ associates with disease progression in human breast cancer. Cancer Res 1992, 52:6949-6952.

44. McEarchern JA, Kobie JJ, Mack V, Wu RS, Meade-Tollin L, Arteaga CL, et al: Invasion and metastasis of a mammary tumor involves TGF-beta signaling. Int J Cancer 2001, 91:76-82.

45. Bierie B, Moses HL: Tumour microenvironment: TGF beta: the molecular Jekyll and Hyde of cancer. Nat Rev Cancer 2006, 6:506-520.

46. Roberts $A B$, Wakefield $L M$ : The two faces of transforming growth factor beta in carcinogenesis. Proc Natl Acad Sci U.S.A. 2003, 100:8621-8623.

47. Lei XF, Bandyopadhyay A, Le T, Sun LZ: Autocrine TGF beta supports growth and survival of human breast cancer MDA-MB-231 cells. Oncogene 2002, 21:7514-7523.

48. Arrick BA, Korc M, Derynck R: Differential regulation of expression of three transforming growth factor/3 species in human breast cancer cell lines by estradiol. Cancer Res 1990, 50:299-303.

49. Shi XP, Miao S, Wu Y, Zhang W, Zhang XF, Ma HZ, Xin HL, Feng J, Wen AD, Li Y: Resveratrol Sensitizes Tamoxifen in Antiestrogen-Resistant Breast Cancer Cells with Epithelial Mesenchymal Transition Features. Int J Mol Sci 2013, 14:15655-15668.

50. Dong M, How T, Kirkbride KC, Gordon KJ, Lee JD, Hempel N, Kelly P, Moeller BJ, Marks JR, Blobe GC: The type III TGF-beta receptor suppresses breast cancer progression. J Clin Invest 2007, 117:206-217.

51. Yingling JM, Blanchard KL, Sawyer JS: Development of TGF-beta signalling inhibitors for cancer therapy. Nat Rev Drug Discov 2004, 3:1011-1022.

52. Rajput S, Kumar BN, Sarkar S, Das S, Azab B, Santhekadur PK, Das SK, Emdad L, Sarkar D, Fisher PB, Mandal M: Targeted Apoptotic Effects of Thymoquinone and Tamoxifen on XIAP Mediated Akt Regulation in Breast Cancer. Plos One 2013, 8:e61342.

53. Kumar BN, Rajput S, Dey KK, Parekh A, Das S, Mazumdar A, Mandal M: Celecoxib alleviates tamoxifen-instigated angiogenic effects by ROSdependent VEGF/VEGFR2 autocrine signaling. BMC Cancer 2013, 13:273.

54. Sarkar S, Mazumdar A, Dash R, Sarkar D, Fisher PB, et al: ZD6474 Enhances Paclitaxel Antiproliferative and Apoptotic Effects in Breast Carcinoma Cells. J Cell Physiol 2011, 226:375-384.

55. Aberg UW, Saarinen N, Abrahamsson A, Nurmi T, Engblom S, et al: Tamoxifen and flaxseed alter angiogenesis regulators in normal human breast tissue in vivo. PLoS One 2011, 6:e25720.

56. Subramaniam V, Chakrabarti R, Prud'homme GJ, Jothy S: Tranilast inhibits cell proliferation and migration and promotes apoptosis in murine breast cancer. Anticancer Drugs 2010, 21:351-361.

57. Shime H, Kariya M, Orii A, Momma C, Kanamori T, Fukuhara K, et al: Tranilast inhibits the proliferation of uterine leiomyoma cells in vitro through G1 arrest associated with the induction of p21waf1 and p53. J Clin Endocrinol Metab 2002, 87:5610-5617.

58. Sato S, Takahashi S, Asamoto M, Naiki T, Naiki-Ito A, Asai K, Shirai T: Tranilast suppresses prostate cancer growth and osteoclast differentiation in vivo and in vitro. Prostate 2010, 70:229-238.
59. Yamamoto M, Yamauchi T, Okano K, Takahashi M, Watabe S, Yamamoto Y: Tranilast, an anti-allergic drug, down-regulates the growth of cultured neurofibroma cells derived from neurofibromatosis type 1. Tohoku J Exp Med 2009, 217:193-201.

60. Prud'homme GJ: Pathobiology of transforming growth factor beta in cancer, fibrosis and immunologic disease, and therapeutic considerations. Lab Invest 2007, 87:1077-1091.

doi:10.1186/1423-0127-20-76

Cite this article as: Darakhshan and Ghanbari: Tranilast enhances the anti-tumor effects of tamoxifen on human breast cancer cells in vitro. Journal of Biomedical Science 2013 20:76.

\section{Submit your next manuscript to BioMed Central and take full advantage of:}

- Convenient online submission

- Thorough peer review

- No space constraints or color figure charges

- Immediate publication on acceptance

- Inclusion in PubMed, CAS, Scopus and Google Scholar

- Research which is freely available for redistribution 